\title{
Britain and the origins and future of the European defence and security mechanism
}

Article

Accepted Version

Heuser, B. (2017) Britain and the origins and future of the European defence and security mechanism. RUSI Journal, 162 (2). pp. 16-23. ISSN 1744-0378 doi:

https://doi.org/10.1080/03071847.2017.1335557 Available at https://centaur.reading.ac.uk/71841/

It is advisable to refer to the publisher's version if you intend to cite from the work. See Guidance on citing.

Published version at: http://dx.doi.org/10.1080/03071847.2017.1335557

To link to this article DOI: http://dx.doi.org/10.1080/03071847.2017.1335557

Publisher: Routledge

All outputs in CentAUR are protected by Intellectual Property Rights law, including copyright law. Copyright and IPR is retained by the creators or other copyright holders. Terms and conditions for use of this material are defined in the End User Agreement.

$\underline{\text { www.reading.ac.uk/centaur }}$ 
Central Archive at the University of Reading

Reading's research outputs online 


\section{Britain and the Origins and Future of the European Defence and Security Mechanism}

\section{Beatrice Heuser}

Lessons learnt from history can be wrong or irrelevant, but one lesson that to a student of international relations seems both right and relevant seems to have been forgotten: that Britain's security depends on a peaceful Europe, that Europe's stability is enhanced by a firm British commitment to the defence of democratic states in Europe, and that the fine skills of British officials have been essential in overcoming many a crisis not only in transatlantic relations, but also in intra-European relations. Yet, today this carefully crafted defence mechanism of Europe, engineered above all by Britain, is crumbling.

This mechanism and the rules to guide its employment took decades to construct, and Britain was one of the leading powers in initiating, amending and then fine-tuning it. In key periods, this was achieved along with France; in others mainly alongside the US and West Germany. It was a mechanism that allowed for dynamism, elasticity and perpetual adjustments to ever new events, which had to be accommodated without undermining the foundations of the entire structure.

The British leaders and officials involved drew on centuries of failed experiments with alternative structures, all of which were eventually unable to keep the British Isles out of the two world wars, resulting in unprecedented numbers of casualties, damage and suffering. The mechanism, designed as much as cobbled together in ad hoc salvage operations by British politicians and defence planners, was at once robust and flexible, allowing it to weather a series of crises. But it relied and relies crucially on Britain as the central lynchpin keeping the construct together. The British withdrawal from the EU risks removing this central lynchpin, upon which the entire construct may come apart.

\section{The Channel Bridged by Airpower}

Centuries of trial and error form the background to the construction of the current European defence mechanism. England and later Britain, along with most other European entities, had long embraced balance of power strategies. But while the rules of the balance-of-power game stopped any one power from dominating Europe, time and again, war was the main instrument available to beat rivalling expansionist powers.

While this might have been seen as a price worth paying while Britain's wars took place outside British territory, the development of new technologies and the stark realities of their application during the two world wars changed this. In the First World War, Britain experienced fatalities on an unprecedented scale, while the advent of airpower mitigated the defensive strength of the Channel. In 1917, the Committee of the Imperial War Cabinet noted that air raids were becoming central to war. From then on, Britain's military planners sensed that Britain could not expect to intervene in wars in Europe without its own territory being endangered. ${ }^{1}$ England had long taken such an interest in Flanders, the Low Countries and France as any invasion of England by sea was likely to come from there. By 1934, however, it was recognised that these areas, in enemy hands, would be the most dangerous launch-pads for air strikes on the UK, given the range of bombers at the time. ${ }^{2}$ In 1941, Britain still stood a chance of fighting off enemy bombers with fighter aircraft, but rapidly changing technology made this configuration obsolete within only three years. The advent of ballistic missiles then heightened Britain's vulnerability to attacks from the air - from wherever they are launched. In short, twentieth 
century developments in military technology have joined the fate of Britain to that of Europe in unprecedented ways.

Britain's increased vulnerability to new military technologies saw a parallel disillusion with classic balance of power politics, of which the First World War was a bloody denouement. In the interwar period, the search for an alternative led to the establishment of a rule-bound system of settling disagreements, in the form of the League of Nations of 1919.

But the League famously foundered in part because the US, an expanding power, was not ready to commit to it. The US interpreted the lessons of the connection between alliance commitments and outbreak of the First World War differently: it was weary of entangling alliances, and as such, League of Nations membership. British misinterpretations were not far off: London regarded France with so much suspicion that it shied away from any a joint peacetime alliance, let alone joint exercises.

\section{Britain Constructs a New Defence and Security Mechanism}

The disastrous consequences of the non-commitment of the UK to European defence in the interwar period brought home to British policy makers the need for a world organisation that, unlike the League of Nations, could be complemented by the presence of countries willing and able to act as world policemen - including not only Britain and France, but also the US.

The decision-making organ of the newly created United Nations, the Security Council, gave a permanent seat (and veto power) not only to Britain, France and the US but also the USSR - the new key player in world politics. Yet as the opposition between East and West consolidated, divergent aims between the USSR and its UN peers soon paralysed the UN. For the same reason, the cooperation among the victor powers on the subject of the future of Europe in general, and Germany in particular, began to break down. By late 1947, the British and French governments saw no future in cooperation with the USSR. ${ }^{3}$

1947 was the next big watershed for Britain in several ways. One was the independence of India and Pakistan, ushering in the end of the British Empire. This allowed the government of Clement Attlee (with its foreign secretary, Ernest Bevin) to give its full attention to the evolving situation in Europe, where Joseph Stalin was perceived as the new brutal and expansionist leader of Europe. Meanwhile the Communist Information Bureau unleashed a propaganda campaign against the West, and Stalin forbade the governments of his satellite states in Eastern Europe to accept Western aid in the form of the Marshall Plan. The first step for Britain was to symbolically make up for that acte manqué, the Franco-British alliance that had been so sorely lacking in the interwar period, by concluding in March 1947 the Dunkirk Treaty, a mutual defence pact against a threat from a revived Germany. ${ }^{4}$

By the end of the year, Bevin wanted to take this bilateral alliance further. He proposed to his French counterpart, Georges Bidault, the creation of 'some sort of federation in Western Europe', in order 'to save Western civilisation', no less. ${ }^{5}$ In analogy with the Franco-British guarantee to Poland in 1939, he wanted London and Paris to guarantee the security of the Benelux countries. As he explained to his Cabinet colleagues on 4 January 1948:

We in Britain can no longer stand outside Europe and insist that our problems and positions are quite separate from those of our European neighbours. Our treaty relations with the various countries may differ, but between all there would be an understanding backed by power, money and resolution and bound together by the common ideals for which the Western Powers have twice in one generation shed their blood. ${ }^{6}$

But the Benelux countries wanted more than a guarantee reminiscent of that which had been made to Poland in 1939. They wanted a defence pact between equals ${ }^{7}$. Attlee and his foreign 
secretary quickly warmed to their idea. On 28 January 1948 Attlee wrote to Bevin about creating, with the planned defence treaty, a European Affairs Committee:

The task of the 'European Affairs Committee' would be to coordinate the working out of practical measures for giving effect to the general policy of promoting political and economic integration of Western Europe, under four heads -

(i) political;

(ii) defence and security;

(iii) publicity and propaganda; and

(iv) economic. ${ }^{8}$

This was followed by Bevin's memorandum to the British Cabinet (the basis for which had already approved by Cabinet), on 3 March 1948: 'we should aim as a matter of great urgency at negotiating multilateral economic, cultural and defensive pacts between the United Kingdom, France and the Benelux countries, which would be left open for accession by other European democracies'.

In March 1948, the UK, France and the Benelux countries signed the Brussels Treaty, creating a Western Union, later re-named Western European Union (WEU). Its key article read:

If any of the High Contracting Parties should be the object of an armed attack in Europe, the other High Contracting Parties will, in accordance with the provisions of Article 51 of the Charter of the United Nations, afford the Party so attacked all the military and other aid and assistance in their power. ${ }^{10}$

If sovereignty is defined as an unconditional retention of the right to decide when and how to use force, then the Brussels Treaty arguably constitutes a partial abrogation of sovereignty - in return for the benefit of greater collective security. However, the Brussels Treaty was not only about creating a defence community, it also provided for cooperation in cultural, social, economic, and political affairs. ${ }^{11}$

The French then asked the US to back this Western Union, resulting in the signing of the North Atlantic Treaty in April 1949. ${ }^{12}$ US involvement in European security was thus the result of an explicit European invitation. ${ }^{13}$

Britain therefore initiated, and subsequently played a key role in, the creation of a (Western) European Union. It was led not only by the Labour government of Attlee - even Winston Churchill, who was then leader of the Conservative opposition to the Labour government, was captivated by these new beginnings. In October 1948, he famously drew a picture of Britain as the lynchpin of three interlinked circles:

The first circle for us is naturally the British Commonwealth and Empire, with all that that comprises. Then there is also the English-speaking World in which we, Canada, and the other British Dominions and the United States play so important a part. And finally there is United Europe. These three majestic circles are coexistent and if they are linked together there is no force or combination which could overthrow them or even challenge them.

Now if you think of the three inter-linked circles you will see that we are the only country which has a great part in every one of them. We stand, in fact, at the very point of junction, and here in this Island at the centre of the seaways and perhaps of the airways also have the opportunity of joining them all together. ${ }^{14}$

Britain had to be part of each of these circles, to join them all together.

It is probably fair to say that the British public was never fully aware of these British origins of European integration, nor of the importance of the defence dimension, nor of the partial abrogation of sovereignty in the form of the unconditional mutual commitment which the WEU 
treaty entailed. Six years later, Italy and West Germany were admitted to the WEU at a time when Britain alone had decided to commit a standing army to Europe indefinitely (the British Army of the Rhine). It also de facto assumed the responsibility, under the Supreme Allied Commander Europe, to lead the defence of Northwestern Europe. British officers commanded the Allied Forces, Northern Europe (AFNORTH), covering Denmark and Norway; the Northern Army Group (NORTHAG); the $2^{\text {nd }}$ Allied Tactical Air Force (TWOATAF), covering West Germany's northern half; and Allied Command Channel (ACCHAN). However, the WEU was deprived of any serious business to carry out when it relegated all measures necessary to underpin its treaty commitments to NATO in the early 1950s, although its mutual guarantee remained central to mutual European reassurance.

Three developments took the wind out of the sails of the British in their drive towards further European integration. The first was the negotiation and eventually the signing of the North Atlantic Treaty in Washington in April 1949, signed by the Brussels Pact powers plus the US, Canada, Denmark, Iceland, Norway, Italy and Portugal. NATO's Article 5 was adapted from the Brussels Treaty text to reduce the unconditional all-out commitment that the Europeans had assumed towards each other. This allowed the US to preserve its sovereign decision-making freedom intact, at the insistence of the US Congress: ${ }^{15}$

The Parties agree that an armed attack against one or more of them in Europe or North America shall be considered an attack against them all, and consequently they agree that, if such an armed attack occurs, each of them ... will assist the Party or Parties so attacked by taking forthwith, individually, and in concert with the other Parties, such action as it deems necessary, including the use of armed force, to restore and maintain the security of the North Atlantic area. ${ }^{16}$

Together with assuming a leading role in the UN, this was part of a turning point in world history, as the US opted for peacetime engagement with the rest of the world. Bevin and Attlee eagerly took advantage of this trend to secure further US commitments to the defence of other parts of the world - the Middle East, Southeast Asia and the Far East - against communist encroachment. The mix of West European mutual guarantees, US backing for European security through NATO and through the Marshall Plan and subsequent political support for European integration allowed an equally revolutionary change to take place in Europe: after centuries of problems bloodily fought over at each other's expense, Europeans turned instead to peaceful cooperation in order to address common problems jointly. The new approach assumed that even major problems affecting just one of them deserved to be addressed through pooling of resources and aid, and working out, multilaterally, solutions to issues that previously might have been addressed by war. This revolution in inter-state affairs was worked out jointly with France, and ultimately included the admission of West Germany to NATO. The result has been the longest period of peace within the area covered by the European Economic Community (EEC)/EU since the collapse of the Pax Romana.

Despite its leading role in getting the process of European integration started in 1947-49, Britain in 1950 relinquished this role in furthering European integration in the non-military dimensions, distracted by the outbreak of the Korean War, and by having to fight counterinsurgencies in Malaya and Kenya. Morever, with the US guarantee secured, Attlee and Bevin - paralysed by a terminal illness - became less enthusiastic about further European defence integration. The creation of the European Coal and Steel Community, outside the Brussels Treaty as West Germany was not yet a member, thus went ahead without Britain.

In addition, in 1951, Labour lost power to the Conservatives under Churchill, who, now that NATO had been created and the other regional security organisations that Bevin had planned were coming into being - the Middle East Treaty Organization and the Southeast Asia Treaty Organization -was no longer interested in joining the continental Europeans in their project of 
economic, social and political integration. Thus Britain remained out of the European Economic Community (EEC) and Euratom which were created in 1957 with the Treaties of Rome.

It would take Britain 20 years to reverse this policy and join the EEC. As its colonies gradually gained independence and Churchill finally retired, Britain's leaders found it difficult to imagine a future for a lonely Britain shorn of its empire. By 1961, the Conservative government of Harold Macmillan regretted not having been present at the creation and bid, tardily, for membership of the EEC. ${ }^{17}$ Harold Wilson's Labour government did so again in 1967. Both membership bids were vetoed by President Charles de Gaulle of France, however, who thought of Britain as Washington's puppet. ${ }^{18}$ Only after de Gaulle's departure was the UK accepted into the EEC (and Euratom) in 1973, along with Denmark and Ireland.

De Gaulle had blocked not only UK accession to the EEC, but also further European defence integration. He had been happy to leave the WEU as a skeletal structure, and prevented the EEC from developing any other defence dimension. While promoting the development of an independent French nuclear arsenal, he steered West Germany and Italy away from dreams of nuclear weapons of their own with empty promises of a European nuclear force developed through Euratom. In fact, he ensured that such a European nuclear force would never come into being: the furthest France would go was to say that French nuclear weapons protected Europe by virtue of being European. ${ }^{19}$ Then in 1967, he pulled his country out of the integrated military structure of NATO, pouring scorn on the notion that a Washington government would risk the survival of its own nation in defence of its European allies, once the US had come within reach of Soviet aircraft and missiles.

\section{The Containment of Nuclear Proliferation in Europe}

De Gaulle was right in one respect: despite the importance of the North Atlantic Treaty in marking the US's rejection of isolationism, there has never been an explicit US nuclear guarantee for Europe. Article 5 of the treaty leaves it open to each treaty partner to undertake 'such action as it deems necessary', that is to say, react in whatever way it sees fit to the attack against any other member of the Alliance. This could be a strongly worded letter of protest, or an all-out nuclear response, but no party is obliged to defend another till the end.

However, NATO relied heavily on US might and manpower, and nuclear weapons. A huge and varied US nuclear arsenal was deployed to Europe creating the possibility for the US president to interpret the North Atlantic Treaty's ambiguously worded Article 5 as a nuclear guarantee on the day if he so wished.

However, US willingness to use these in the defence of Europe - the essence of the deterrence posture needed, it was thought, to keep the Soviets out and the European countries from craving their own nuclear weapons - was visibly waning once Soviet intercontinental ballistic missiles (ICBMs) and bombers could reach US soil. Leading US government strategists now favoured an alternative to a nuclear defence of Europe: the limitation of any defence of Europe to purely 'conventional' weapons. Under the label 'flexible response', the US tried to sell this alternative to nuclear defence to its European allies in the early $1960 \mathrm{~s}^{20}$

This could have been the end of NATO. The Europeans had lived through a 'merely conventional' war in Europe, and were not prepared to do so again. For them - including Britain - nuclear deterrence was the only option. ${ }^{21}$ Already in 1946 Bevin had proclaimed that he wanted a nuclear bomb at all costs, so as to speak as an equal to the Americans. ${ }^{22}$ De Gaulle wanted this status as well, with a French nuclear force controlled by none but France itself. It would have taken little for other European powers to follow suit. Even neutral Switzerland, Sweden and Finland worked on their own nuclear programmes. West Germany, Italy, The Netherlands, Greece and Turkey were keenly interested in the creation at least of a multinational nuclear force, 
independent of a US veto. ${ }^{23}$ And other states - China, South Africa, Israel, India, Brazil among them - all vigorously pushed their own nuclear research, some of them actually becoming nuclear weapons owning states, whether declared or undeclared.

The response from the US, the USSR and Britain was to ask the non-nuclear powers of the world to abstain voluntarily from developing nuclear weapons. These efforts resulted in the 1968 nuclear Non-Proliferation Treaty (NPT), which only entered into force in 1970; West Germany, Italy and the three Benelux countries only ratified it in 1975 in the benign climate of East-West Détente, and after other hopes of a European nuclear force had died. France acceded to the NPT only in 1992.

In this context it was often argued that the only way a nuclear power can justify its ownership of nuclear weapons while denying it to others is by assuring the non-nuclear powers of its readiness to come to their defence if attacked. ${ }^{24}$ The containment of proliferation in Europe was the function of a delicate balance of factors, including US reassurance, perceptions of the Soviet threat, the lay of one's own land in relation to possible Warsaw Pact military operations, the ability of one's own country to resist occupation, historical experiences and cultural attitudes to war, and several other trade-offs. The resulting balance persuaded several countries in the far north or with mountain redoubts to withdraw to wind down their own nuclear weapons programmes.

Countries that would have lain in the path of a main Warsaw Pact onslaught on the Central Front were less taken with the Bonn government hesitated to sign the NPT. ${ }^{25}$ As the US willingness to defend NATO Europe with nuclear weapons was brought into question, one might have expected NATO's other two nuclear powers, both Britain and France, to step into the breach. France did not. Since de Gaulle's, successive French governments have, on the whole, avoided any interpretation of France's defence commitment to its allies in the Brussels Treaty as a nuclear guarantee (sometimes arguing that this commitment was originally made before France had nuclear weapons, and thus that it could not concern these). ${ }^{26}$

Britain, however, did, and in doing so rescued Western defence cooperation, now largely taken care of by NATO. UK defence officials worked out compromise solutions which hinged on Britain's declared willingness and technical ability to use nuclear weapons in defence of its European NATO allies, even if the US hesitated to do so - going so far as showing this in exercises. The British persuaded Washington to allow the construction of a Nuclear Planning Group (NPG) within NATO where non-nuclear weapons owning partners could formulate with the US and UK, jointly, principles for initial use of US and UK nuclear weapons acceptable to all sides. Britain engaged closely with the West German defence community, listening to their concerns about the British preference for battlefield nuclear weapons that would devastate German territory, and eventually supporting Bonn in its campaign to rid NATO of atomic demolition munitions and other weapons of the shortest ranges. Throughout, British governments took extremely seriously their unconditional commitment to the defence of their allies. $^{27}$

The British component of nuclear deterrence was certainly not the only thing holding up the entire mechanism - there were also the US, Canadian, and native conventional forces in Europe, and missiles given to non-nuclear allies that would have been armed with nuclear warheads when the US decided to release them, the well-rehearsed command-and-control procedures, the exercises to airlift further forces to Europe upon demand, and many other factors. Nevertheless, British reassurances, British efforts to create the NPG and to make the US listen to European concerns, and British support - especially for Germany's requests, as a front line state, to move the theatre of nuclear war further to the east, and away from German soil, all made crucial contributions to the survival of this mechanism. This kept the delicate machinery of Western defence working despite divergent US and European strategy preferences.$^{28}$ Germans, Italians 
and other NATO members desisted from developing nuclear weapons and stayed in NATO. Even European states that were not NATO members thought that this mechanism would be enough to deter any Warsaw Pact attack and renounced their nuclear programmes.

\section{European Defence after the Cold War}

From the late 1960s until the end of the Cold War, NATO's structures and consultation-, defence-, and nuclear release-procedures would be central to the functioning of NATO. However, after the end of the Cold War, this machinery was hugely scaled back and key nuclear procedures practised only among tiny groups of actors since the abandonment in the early 1990s of NATO's large-scale Wintex command post exercises. ${ }^{29}$ Conventional scenarios were updated and acted out in NATO's Crisis Management Exercise scenarios, but this also meant that procedures for major war scenarios have been all but forgotten.

Meanwhile Europeans asked whether the end of the Warsaw Pact and of the Soviet Union did not mean, logically, that the US would reduce its commitment to European defence, which was feeble in treaty terms, but strong in terms of deployment of forces to Europe and support for NATO's infrastructure on all levels. As the latter was and is a matter of choice, the US could freely reduce it at any time. France in particular tried to endow the EU with its own defence apparatus, pushing for a European Common Foreign and Security Policy, or even a common European Security and Defence Policy (ESDP). Some wanted to extend WEU membership so as to make it the organisation that could shoulder the responsibilities of the ESDP. Britain consistently vetoed all attempts to build up such a European defence mechanism outside NATO and in parallel to NATO, arguing that this would unnecessarily duplicate efforts, waste resources and increase the incentives for the US to withdraw from Europe. ${ }^{30}$ In the 1990s and 2000s, several European initiatives to give more European substance to a European pillar of NATO that could stand alone if needed led to meagre results. This was in the absence of a clear and present threat perception, consequent pressures to reduce defence spending to finance many other pressing needs, and with France's persistent refusal to proclaim itself a nuclear guarantor for all its WEU allies despite the text of the treaty. ${ }^{31}$ Finally, in 2010, the WEU's mutual defence clause was folded into EU's Lisbon Treaty, where Article 42.7 reads:

If a Member State is the victim of armed aggression on its territory, the other Member States shall have towards it an obligation of aid and assistance by all the means in their power, in accordance with article 51 of the United Nations charter. ${ }^{32}$

While the WEU ceased to exist in June 2011, the all-out, unconditional commitment to mutual defence, which cannot in good faith be read as anything short of a nuclear guarantee, continues to exist - not in NATO, but among EU members only.

\section{The Future of European Security}

Breaking away from the EU and from the security commitment now contained in the Lisbon Treaty, places the British Isles in a situation unlike any since the Norman Conquest. Cut loose both from its former colonial empire that only survives in the cobweb-thin security links with the Commonwealth, and from the EU, Britain will have only NATO to draw on as a force multiplier. Yet NATO has developed away from the large integrated defence structures it had during the Cold War, which alone made the minimal promises of its Article 5 worth more than the full commitment of the Brussels Treaty. Moreover, the US has incrementally turned its main attention towards East Asia and away from Western Europe. With Britain's withdrawal from the EU, Europe is losing the unconditional treaty commitment of the one power that kept NATO from falling apart several times. 
Britain may be only a medium player on the world scene, but it has occupied a pivotal role in European security, with influence far greater than its size. Among EU member states, only France and Britain have permanent seats on the UN Security Council, and see themselves responsible for law and order in the world, with an obligation to send armed forces to in the manner of police forces in domestic contexts. ${ }^{33}$ Yet neither can do much any longer without allied support, not even a fairly limited intervention such as the 2013 French operation in Mali. Meanwhile, Germany is still weighed down and limited in its actions by the burden of its past, and the other middle-size powers - Italy, Poland, Spain - are economically too weak to pull their weight, and show not particular desire to do so. Thus Britain and France have returned to bilateralism with their Saint Malo Declaration of 1998 and of Lancaster House Agreement of $2010 .^{34}$ (And even this, as Peter Ricketts argues, was intended at the time not merely as a bilateral endeavour, but as a step towards greater European co-operation.

As European defence integration stalled since the 1950s - until 1991, because NATO was the bigger and more potent alternative, and from 1991, as the sense of urgency had gone, Britain turned towards these and several other bilateral agreements as force multipliers and alternative to exclusive reliance on the USA. All of them were concluded even before the British referendum on EU membership (for example with Denmark in 2012 or Sweden days before the British referendum in 2016). Since Brexit, there seems little alternative for Britain to the bilateralism that was ominously characteristic of the first half of the twentieth century, and, of course, its continuing, traditional strong reliance on NATO.

As Russia attempts to reassert its hold on Eastern Europe and Donald Trump's foreign policy remains unpredictable, today it matters more than ever that NATO's Article 5 commits members to do only what they see fit if one of their allies is attacked.

Gone is the unconditional British nuclear guarantee of its non-nuclear allies in the WEU and then the EU Lisbon Treaty. No wonder, then, that there are voices in Germany asking whether the conditions under which the NPT was signed still pertain. ${ }^{35}$ Interest in nuclear weapons is also voiced, understandably, in Poland. ${ }^{36}$

The Europeans have every interest today in finally taking their defences firmly in their own hands, and in theory, there are enough of them to do so: no longer are Britain and France the only democracies able to act as they were immediately before and after the Second World War. ${ }^{37}$ With 28 members claiming to share the values of democracy and human rights that Bevin evoked back in 1948, the EU should be well able to defend itself, if persuasive leadership could finally overcome bureaucratic inertia and democratic tendencies to appease dictators rather than to increase defence spending. But since 1948, the Europeans have singularly failed to get their act together in matters of defence when Britain did not push for it or dragged its feet.

Moreover, instead of greater defence integration, there is a fracturing of security concerns within the EU. Its northern and northeastern members are frightened by Moscow's treatment of neighbouring countries, while a swathe of countries including France, Belgium, The Netherlands and Germany worry about terrorism and the Southern Mediterranean littoral states are preoccupied with domestic worries, aggravatedby streams of refugees not only from war-torn Syria, but also from Afghanistan and sub-Saharan Africa. The construct that has kept most parts of Europe safe since the late 1940s - European political, economic and social integration, plus the NATO structures, plus the underlying reassurance of the Brussels Treaty's mutual European guarantee - is crumbling.

Yet it is now of all times that Britain is relinquishing the leadership it has exercised in European defence for almost eight decades since 1939. The lynchpin is being withdrawn from the European defence and security mechanism - yet much of the political debate on the UK's 2016 referendum on EU membership or indeed since has been about issues other than security and defence. 
Yet it is the future of Europe's security that is at stake, and British leadership is again needed urgently. The most practical answer might be a revival of the Western European Union, or the creation of an unconditional defence commitment on its lines, and the adaptation and parttransformation of existing NATO structures to underpin it with the means of implementing such mutual guarantees. In an age of air and space power, and of cyberwarfare, nobody is an island.

The author would like to thank the following colleagues for comments and suggestions: Professors Geoffrey Warner, Ann Deighton, Leopoldo Nuti, Lori Maguire Georges-Henri Soutou and Brendan Simms, as well as Ambassaor (ret) Greg Schulte, Diego Ruiz. Palmer and Brigadier (ret) Michael Clemmessen. All remaining errors are none but ber own.

\section{Notes}

1 Michael Howard, The Continental Commitment: The Dilemma of British Defence Policy in the Era of the Two World Wars (1972, repr. London: Ashfield Press, 1989), p. 81.

2 Ibid., p. 110

3 Elisabeth Barker: The British between the Superpowers, 1945-1950 (London: Macmillan, 1983); Robert Pearce: Attlee's Labour Governments, 1945-1951 (London: Routledge, 2006).

4 Documents of British Policy Overseas, henceforth DBPO, Series I,Vol. XI, pp. 528-530.

5 DBPO, I.X, p 3.

6 DBPO Series I, Vol. X, p. 15

7 Ibid.

8 DBPO, I.X, p. 42.

9 DBPO, I.X, p. 87.

10 This was Article IV in the original treaty, and after its revision in 1954 to accommodate Italy and West Germany as new members, it became Article V. It was then referred to as Article V of the revised Brussels Treaty until it was wrapped into the EU's Lisbon Treaty of 2010, see below. Author's italics.

11 http://www.cvce.eu/en/obj/the brussels treaty 17 march 1948-en-3467de5e-9802-4b65-8076778bc7d164d3.html, accessed on 19 XII 2016.

12 DBPO, I.X, p. 104.

13 For the Commonwealth origins of these ideas, see Andrew Baker: Constructing a Post-War Order: The Rise of US Hegemony and the Origins of the Cold War (London: I.B. Tauris, 2011).

14 Winston S. Churchill, 'Conservative Mass Meeting: a speech at Llandudno, 9 October 1948', Europe Unite: speeches 1947 \& 1948 (London: Cassell, 1950), p. 416-418

15 Cees Wiebes and Bert Zeeman: 'The Pentagon Negotiations March 1948: The Launching of the North Atlantic Treaty' International Affairs Vol. 59, No. 3 (Summer, 1983), pp. 351-363.

$16 \mathrm{http://www.nato.int/cps/en/natohq/official} \mathrm{texts} \mathrm{17120.htm} \mathrm{accessedon} 19$ XII 2016, my Italics.

17 Wolfram Kaiser: Using Europe, Abusing the Europeans: Britain and European Integration, 1945-63 (London: Macmillan, 1996).

18 Beatrice Heuser: 'Britain, France and the Bomb: the Parting of Ways between Suez and Nassau', Storia delle Relazioni Internazionali Vol. XIII No. 3 (Autumn 1997), pp.75-94.

19 Beatrice Heuser: NATO, Britain, France and the FRG: Nuclear Weapons and Forces for Europe (London: Macmillan, 1997), chapter 4.

20 Catherine McArdle Kelleher: Germany and the politics of nuclear weapons, (New York: Columbia University Press, 1975); Elizabeth Sherwood: Allies in Crisis (New Haven, Ct.: Yale University Press, 1990); Christoph Bluth: Britain, Germany and Western nuclear strategy (Oxford : Clarendon Press, 1995). 
21 Ibid. [Heuser: NATO, Britain, France and the FRG], chapters 1-3. Note the three different meanings of 'flexible response' from the use of the term in NATO in the late 1950s to its use form the late 1960s onwards.

22 Alan Bullock: Ernest Bevin, Foreign Secretary, 1945-1951 (Oxford: Oxford University Press, 1985), p. 352.

23 Barbier, Colette: "La force multinationale", Relations Internationales No. 69 (Spring 1992); Leopoldo Nuti: 'Extended Deterrence and National Ambitions: Italy's Nuclear Policy, 1955-1962', Joumal of Strategic Studies Vol. 39 No. 4 (2016), pp. 559-579.

24 Beatrice Heuser: 'Beliefs, Cultures, Proliferation and Use of Nuclear Weapons', in Eric Herring (ed.): Preventing the Use of Weapons of Mass Destruction Special Issue of Journal of Strategic Studies Vol. 23 No. 1 (March 2000), pp.74-100.

25 Hal Brands: 'Non-proliferation and the Dynamics of the Middle Cold War: The Superpowers, the MLF, and the NPT' Cold War History Vol.7 No. 3 (2007), pp. 389-423; Andreas Lutsch: 'Inevitable But Highly Controversial? The Accession of the Federal Republic of Germany (FRG) to the NPT (19671975)', SHAFR annual conference. 2013.

26 Nicolas Roche: Pourquoi la Dissuasion (Paris: PUF, 2017), pp. 52-85.

27 Ivo Daalder: The Nature and Practice of Flexible Response: NATO Strategy and Theater Nuclear Forces Since 1967 (New York : Columbia University Press, 1991); Christoph Bluth: Britain, Germany and Western Nuclear Strategy (Oxford: Clarendon Press, 1995); Heuser: NATO, Britain, France and the FRG, chapters 3 and 5.

28 Kristan Stoddart: Losing an empire and finding a role : Britain, the USA, NATO and nuclear weapons, 1964-70 (Houndmills, Basingstoke, Hampshire ; New York : Palgrave Macmillan, 2012); id.: The sword and the shield: Britain, America, NATO, and nuclear weapons, 1970-1976 (Basingstoke: Palgrave Macmillan, 2014).

29 Ilay Ferrier: 'NATO's Exercises', forthcoming in Beatrice Heuser, Diego Ruiz Palmer, Tormod Heier and Guillaume Lasconjarias (eds): The Political Dimensions of Military Exercises (Rome: NATO Defence College, forthcoming 2018).

30 Trine Flockhard and G. Wyn Rees: 'A Core Europe? The EU and the WEU', in William Park and G. Wyn Rees (eds.): Rethinking Security in Post-Cold-War Europe (Abingdon: Routledge, 1998), pp. 6179 .

31 Jolyon Howorth \& John Keeler: 'The EU, NATO and the Quest for European Autonomy'; in Jolyon Howorth \& John Keeler (eds): Defending Europe: the EU, NATO, and the Quest for European Autonomy (Basingstoke: Palgrave Macmillan, 2003), pp. 3-21; Jolyon Howorth: Security and Defence Policy in the European Union (2nd edn Basingstoke: Palgrave Macmillan, 2011).

32 http://eur-lex.europa.eu/legal-content/EN/TXT/PDF/?uri=OJ:C:2007:306:FULL\&from=EN accessed on 19 XII 2016. As the United Kingdom and France own nuclear weapons, there is no logical reason why this should not be interpreted as a nuclear guarantee. Author emphasis.

33 For France's self-perception as world policeman, see David Chuter: Humanity's soldier: France and international security, 1919-2001 (Providence, RI: Berghahn, 1996)

34 https://www.consilium.europa.eu/uedocs/cmsUpload/FrenchBritish $\% 20$ Summit $\% 20$ Declaration, \%20Saint-Malo,\%201998\%20-\%20EN.pdf, accessed 18 III 2017; and

https://www.gov.uk/government/uploads/system/uploads/attachment_data/file/238153/8174.pdf accessed on 18 III 2017.

35 Frederick Studemann: 'Germans think the unthinkable on going nuclear', Financial Times (7 Feb 2017).

36 'Kaczyński befürwortet atomare Aufrüstung in Europa' http://www.zeit.de/politik/ausland/201702/polen-jaroslaw-kaczynski-atommacht-europa (6 Feb 2017).

37 Besides Jolyon Howarth, Julian Lindley French has frequently and eloquently made this point: 'In the Shade of Locarno? Why European Defence Is Failing', International Affairs Vol. 78 No. 4 (Oct., 2002), pp. 789-811. 